\title{
The social life of sediment
}

\author{
Giacomo Parrinello ${ }^{1} \cdot$ G. Mathias Kondolf ${ }^{2}$ (I)
}

Received: 4 February 2021 / Accepted: 8 April 2021 / Published online: 22 June 2021

(c) The Author(s) 2021

\begin{abstract}
Sediment is an essential component of water and river systems. The anthropogenic alteration of sediment fluxes in the world's rivers is one of the principal markers of the Anthropocene, the new geological epoch characterized by human influence at the planetary scale. In spite of its environmental and historical importance, water and river histories have surprisingly neglected sediment until recently. This introduction to the special issue "The Social Life of Sediment" argues for putting sediment at the center of social and historical inquiry and discusses the potential and value of such an approach. To do so, we introduce the concept of the "social life of sediment," that is, the idea that the existence and movement of sediment is entwined with social needs, values, and activities, and needs to be appraised in his historical dimension. We review recent literature in fluvial geomorphology, social sciences, and history to assess to what extent the social and historical life of sediment has been taken into account. After this interdisciplinary review, we present the seven papers of the special issue and highlight their major insights to the study of social and historical lives of sediment. We conclude by outlining avenues for further research and by summarizing what we all can gain from putting sediment at the center of historical inquiries.
\end{abstract}

Keywords Sediment · Anthropocene $\cdot$ River history $\cdot$ Water history $\cdot$ Geosocialities · Fluvial geomorphology

\section{Sediment, society, and history}

Rivers and water systems are much more than water. They are also fluxes of sediment, nutrients, organic matter, and organisms. Fluxes of sediment-gravel, sand, clay resulting from rock weathering and soil erosion, and transported by water-are fundamental. Sediment is essential to aquatic habitats, participates in the making (and unmaking) of agricultural soils, and shapes rivers' channels and flood regimes. It is essential to coastal formations such as deltas and beaches, which depend on the constant contribution of sediment from upstream catchments. Sediment has also quite a turbulent history. Hydroelectric

G. Mathias Kondolf

kondolf@berkeley.edu

Center for History at Sciences Po (CHSP), Paris, France

2 Department of Landscape Architecture, University of California Berkeley, Berkeley, USA 
dams, canals, and sand and gravel mining have altered sediment fluxes so extensively as to produce "sedimentary crises" in many river systems of the world (Bravard 2018a), including the retreat of many of the world's river deltas (Kondolf and Piégay 2011; Kondolf et al. 2014; Bravard 2018b). The alteration of sediment fluxes is one of the processes evoked in larger discussions on Anthropocene, the geological epoch proposed by Crutzen and Stroemer (Crutzen and Stoermer 2000; Crutzen 2002; Steffen et al. 2011) in which anthropogenic influences dominate several geological processes of the planet. For millions of years, rivers have been the most important operators of sediment transport in the planet. By altering soil and water use in river catchments, modern humans have profoundly altered the flux of sediment transported by rivers. Moreover, modern humans have also directly intervened in sediment transport through dredging and construction projects. Through these means, humans have become major geomorphological agents of sediment transport worldwide (Hooke 2000; Syvitski and Kettner 2011). This special issue brings into focus this essential yet neglected component of river and water histories.

The scale and scope of Anthropocene sediment flux alteration, and its consequences on human communities, demand a thorough reappraisal of the links between sediment, society and history. Current sedimentary crises show that any sound understanding of sediment in today's world cannot be divorced from consideration of the role that "social" processes play in reconfiguring sediment fluxes. They also show how transformations and concerns that we would consider thoroughly "social," such as the well-being of human communities, depend as well on sediment and sediment fluxes. This is the first basic but important meaning that we give to the idea of the "social life of sediment".

With the idea of the "social life of sediment," we refer to the fact that the existence and movement of sediment is entwined with social needs, values, and activities. The concept of the "social life of things" was put forward by Arjun Appadurai in an important edited collection of the same title (Appadurai 1986). In his insightful introduction, Appadurai made it clear that he was interested in what he called the "commodity stage" of the life histories of things. For Appadurai, the social life of commodities derives from human values in the context of exchange. While he argued that the "social life" of things is not limited to the "commodity stage," he did not elaborate on how one could conceive the social life of things outside the commodity stage. To be sure, the social life to which Appadurai makes implicit reference seems to be limited to the sphere of meanings. In our use of the phrase "the social life of sediment," we look at the way sediment participates in social assemblages not only through meanings but through material powers and actions. Our use of the phrase "the social life" is thus much akin to approaches such as that put forward by Bruno Latour, who seeks to redefine the "social" altogether by opening it to material agencies (Latour 2007).

We argue that the social life of sediment needs to be appraised in its historical dimension. History provides the necessary temporal depth to understand the social entanglements of present day geomorphological processes. The processes and transformations responsible for the alteration of sediment fluxes occur over long time scales, and altered sediment distribution and transport may persist long after the causative landscape disturbance has ceased. In the eastern USA, very high erosion rates from upland agricultural fields in the nineteenth century decreased by the mid-twentieth century. However, much of the sediment eroded from upland fields was stored in floodplains and small valley bottoms, from where it continued to supply modern rivers. As a result, sediment loads of the rivers remained high even when the activities that generated it were gone (Meade 1982). This is an example of what we may call the "long memory" of rivers. Likewise, sediments can store pollutants for very long times and release them decades, if not centuries, after bygone industries produced the chemical compounds (Ayrault et al. 2021). 
Sediment, in turn, helps make better sense of the history of water systems. Sediment fluxes have shaped water and river engineering projects from siltation of irrigation canals to sedimentation of hydroelectric reservoirs. Sometimes, sediment fluxes have been the main target of river engineering projects. In 1604, for instance, the Republic of Venice diverted the main stem of the Po River to alter the direction of the Po delta progradation and prevent the siltation of the lagoon (Cazzola 1990). Changing sediment fluxes, and resulting water and landscape transformations such as river flooding, land sedimentation, or land subsidence have historically triggered conflicts and controversies. One could not understand them fully without considering sediments themselves, their properties, their spatial scales, and their temporality.

Moving from these considerations, this special issue puts together contributions from fluvial geomorphologists, environmental historians, and historical geographers who lookfrom a variety of case studies and with different methodological approaches-at the historical intersection between sediment and society. Resulting from an international workshop held in Berkeley in the spring of 2019, these contributions demonstrate the interest and value of thinking about the social and historical life of sediment, and of writing accounts that take it seriously. In this introduction, we review existing scholarship on sediment and society in the social sciences and history in particular, as well as in fluvial geomorphology. We then discuss the contribution of the papers collected in this special issue to further the scholarship on this topic. In the conclusive section, we seek to qualify better the idea of the social and historical life of sediment as a path forward for scholarship on sediment in water history and beyond.

\section{Geomorphology and the social sciences}

How has existing scholarship taken into account the intersection of sediment, society, and history? Fluvial geomorphologists have been concerned for a long time with historical processes, but they have commonly avoided engaging deeply into the social and political dynamics responsible for the human alterations to river systems. Social sciences scholars have recently contributed important insights into the social life of sediment. These investigations, however, lack temporal depth.

Fluvial geomorphology has not been blind to anthropogenic influences in geomorphic processes, but has rarely engaged directly with insights from the social sciences and history. As shown by historian Etienne Benson, in spite of attempts at moving the discipline toward abstract mathematical models, fluvial geomorphology has remained rooted in place-based and historical understanding of rivers (Benson 2020). In the discipline, moreover, there is increasing recognition of the "co-production of river science and social order" in river management (Bouleau 2014). This is clearly true for the supply and transport of sediment. In a 2000 article, Roger Hooke sketched the history of anthropogenic alterations of sediment fluxes from the Paleolithic to the present time (Hooke 2000). The links between human history and sediment alteration have become even more prominent in the light of debates on the Anthropocene (Syvitski and Kettner 2011). Much of the fluvial geomorphic literature has concerned anthropogenic alterations in river processes triggered by large changes in sediment yield due to historical human activity: either increases, such as from gold mining in the Sacramento River drainage documented by Gilbert (1917), or decreases, from sediment trapping in dams (Williams and Wolman 1984) and removal of sand and gravel from river beds for 
construction aggregate (Kondolf 1994). These anthropogenic changes in sediment budgets have been important learning opportunities in fluvial geomorphology, yielding diagrams that have appeared in textbooks. Most geomorphological literature, however, has tended to draw upon explanations based on principally on natural sciences (Ashmore 2015). Such studies have commonly focused on the biophysical changes and have not explored the underlying socio-economic drivers, probably out of respect for disciplinary boundaries and cognizance of likely expectations of reviewers for technical journals.

Exceptions exists, of course. These include Ashmore's (2015) history of the development of Highland Creek, Toronto. In Ashmore's account, the Highland Creek's morphological changes result from both societal interventions (clearing settlements from the valley floor for flood control and siting of sewer mains and other utilities down the valley bottom) and natural processes such as large floods, with the resulting "morphology...explained through the co-evolution of the social and natural systems." Ashmore's approach contributes to the broader effort to bridge the gap between the physical and social sciences in the emerging field of Critical Physical Geography (Ashmore 2018; Lave et al. 2018). As discussed by Kondolf and Piégay (2011), many geomorphological features result from closely coupled human and natural systems. An example of this is the "beach nourishment" program of the US Army Corps of Engineers. Sand is mechanically added to eroding beaches to protect vacation houses threatened by erosion. The added sand results in wider beaches and perception of greater protection, increasing the value of coastal properties and thereby encouraging further development, thus creating greater incentives to continue (and even increase) beach nourishment programs ( $\mathrm{McNa}-$ mara and Werner 2008). Studies that explore not only biophysical processes but also the underlying socio-economic drivers remain exceptions, however.

Political ecologists and anthropologists have been paying growing attention to sediment. Political ecologist Christos Zografos, for instance, investigated the politicization of sediment fluxes in controversies on the Ebro Delta in Spain (Zografos 2017). While his focus is not sediment per se, but rather the choices the state makes in ensuring human security in the face of climate change, sediment is important in his account. Sediment scarcity contributes to the subsidence of the Ebro delta and hence to putting the delta's communities at risk. Some actors thus plead for sediment management instead of hard defense structures as a solution to coastal erosion. In their study on "infrastructural standardization events," political ecologist Josh Lewis and anthropologist Ashley Carse have also included sediment (Carse and Lewis 2017). They show that the introduction of new global shipping standards demands morphological transformations to US harbors. This often includes dredging sediment from river mouths. Sediment dredging and disposal, in turn, generates conflicts and highlights opposing views and valuations of sediment and its properties. "Excavating and moving underwater material," Carse and Lewis have more recently claimed, "is as much a social, economic and political phenomenon as it is an intervention in hydrological and geomorphological processes." (Carse and Lewis 2020, p. 11). In a similar vein, in the account of his explorations of the Mississippi and Rhone deltas, Matthieu Duperrex has emphasized the need to pay attention to the materiality of sediment in the assemblages that constitute our landscapes. By so doing, he argues for the need to bring "sediment into politics," including it into our conversations and choices about the configuration of our landscapes and the ways of inhabiting them (Duperrex 2019, p. 27). Monica Barra, in a recent piece on the Barataria sediment diversion project in the Mississippi delta and the opposition of the local African American community, shows compellingly how sediment politics can overlap with long-standing questions of racial and environmental justice (Barra 2021). 
A particularly rich cluster of social science reflections has emerged-perhaps unsurprisingly - on the Bengal delta. The sedimentary landscape of the Bengal delta is constantly shifting, due to the heavy sediment load of the Ganges and Brahmaputra Rivers emptying in it, as well as the effect of the monsoon on seasonal discharge. Sediment, one could argue, imposes itself on any social scientist approaching the shifting terrain of the Bengal delta. Anthropologist Luisa Cortesi has explored the way in which sedimentary landscapes-what she calls "mud"-participate in the construction of contested identities and the enforcement of class and gender divides in riverine communities of the Bengal delta (Cortesi 2018). Using three nested case studies, political ecologists Lafaye de Micheaux, Mukherjee, and Kull have put forward a theoretical framework that seeks to incorporate sediment into existing understandings of the "hydro-social cycle." Including sediment into hydro-social analyses, they argue, allows us to move past the land/water divide still too current in water research. It also points the way to incorporating a broader range of materials in the study of river and water systems (de Micheaux et al. 2018). Lindsay Bremner's work on "monsoon assemblages" in the Bengal delta has similarly argued for the need to take into account the social and political agency of sediment and incorporate it into analyses of territory and power. Building on emerging studies of "geosocialities" (Palsson and Swanson 2016; Yusoff 2018), she argues that sediment is a product of a dynamic Earth system that participates in political assemblages: sedimentary processes are mobilized for specific political agendas, but they have also the power to unsettle such agendas (Bremner 2020a, b).

\section{Sediment in environmental and water history}

While this emerging body of scholarship provides important insights into the social life of sediment and its politics, it says little about the historicity of sedimentary assemblages. What about historians? While many historians have included sediment in their accounts, sediment itself has rarely been the center of the historical inquiry.

River and water history seems to suffer from what we call a "water bias," that is, an exclusive or predominant focus on water to the detriment of the other materials that are part of river and water systems. Environmental and water histories have indeed only sporadically taken into account sediment. In his classic account of irrigation in the American West, Donald Worster offers occasional mentions of sediment and sedimentation, by referring for instance to the need for dredging the Colorado River to prevent siltation of waterworks (Worster 1985, p. 201). Marc Cioc's "eco-biography" of the Rhine pays attention to the sedimentary consequences of channelization works and reservoirs, as well as to the chemical pollution of sediment (Cioc 2002, pp. 47-75, 183-200). Sediment, however, occupies only a relatively small part of Cioc's work and it remains limited to a consideration of the environmental consequences of infrastructure and pollution on sediment, rather than the social and political history of sediments themselves. Histories centered on industrial appropriation of water resources, on water politics, and on the political economy of water have also remained for the most part insensitive to the role and agency of sediment and sedimentary processes (Steinberg 1991; Barca 2010; Swyngedouw 2015). So have histories of river development at the intersection of science, technology, and the environment, starting with Richard White's foundational work on the Columbia River (White 1995; Evenden 2004; Pritchard 2011; MacFarlane 2014). Molle's (2009) overview of the history of river basin planning does not mention sediment at all, correctly reflecting the 
near absence of sediment in the literature. In his stimulating and broad-ranging review of the field of river history and its possible paths forward, Matthew Evenden encourages river historians to engage with the Anthropocene, but tellingly does not include sediment or geomorphological processes in his outlook (Evenden 2018).

Sedimentary processes have played a bigger role in historical accounts of soil erosion and the impacts of mining. In his pioneering history of hydraulic mining in the Sacramento River valley, Robert Kelley investigated the legal conflict between mining companies and downstream communities at the end of the nineteenth century (Kelley 1959). Hydraulic gold mining caused rapid, massive erosion in the Sierra Nevada of California, which resulted in increased sedimentation in valley reaches downstream, burying agricultural lands and increasing the flooding of cities. Kelley's account takes sediment and sedimentation very seriously, making them co-actors in political conflicts. His argument, however, centers on the relationship between state and capital in US history, of which the hydraulic mining controversy was a defining moment, rather than sediment and society. John McNeill also discusses sediment and sedimentation in a major study on soil erosion in five Mediterranean mountain ranges during the nineteenth century (McNeill 1992). McNeill argues that deforestation and the resulting soil erosion increased the sediment load of rivers, causing flooding and damages downstream as well as reshaping the morphology of coastal areas. In spite of this extensive and informed discussion, the center of his work was the nexus of institutional, economic and social processes responsible for deforestation and soil erosion in the mountain slopes, much less on its consequences on sedimentation or on the social and historical trajectories of the sediment thus mobilized. Historical scholarship on soils has otherwise focused more on agriculture and loss of soil productivity via soil erosion than on sediment fluxes in river basins (McNeill and Winiwarter 2010).

Attention to sediment and sedimentation has been growing considerably in environmental and water history over the last decade. Emerging environmental historiography of the coast increasingly includes sediment in its accounts. Elsa Devienne's new history of Los Angeles beaches in the twentieth century recounts the monumental program of beach nourishment which literally made L.A. beaches as we know them, and investigates how this engineered sedimentary landscape shaped new coastal cultures (Devienne 2020). Recent work on the Mediterranean coast has emphasized the role of coastal sediment flux in challenging social uses of the coast and in driving policy and infrastructure choices over the nineteenth and twentieth centuries (Parrinello et al. 2019). Joana Gaspar de Freitas focuses on the movement and attempted stabilization of sand dunes in modern times, seen as an instance of non-human agency in the Anthropocene (Freitas 2020).

The pioneering teamwork on the Viennese Danube published in this journal has investigated long-term geomorphological processes that have shaped the urbanization of Vienna (Winiwarter et al. 2013). This included sedimentary processes responsible for the shifting morphology of the Danube's floodplain and of the human uses and occupation of it (Hohensinner et al. 2013). Maurits Ertsen's history of the Gezira irrigation scheme discusses the challenges that sediment and sedimentation posed to engineering and management (Ertsen 2016). Recent histories of the Yellow River have also made sediment more central to the inquiry than in past river historiography. David Pietz's history of the Yellow River analyzes the role of sediment in water management and engineering concerns during Mao-era energy and irrigation megaprojects (Pietz 2015). Likewise, Ling Zhang's history of the Yellow River avulsion event in $1048 \mathrm{CE}$ devotes considerable attention to sedimentation processes, their causes and consequences, and the attempts to manage them (Zhang 2016). Ding (2020) and Muscolino (2020) have described how sediment availability became a target of state-led management strategies to counter erosion, explicitly 
targeted at reducing sedimentation of the Yellow River's lower reaches and of its reservoirs. Like other social scientists, historians of the Bengal delta and its rivers have also explicitly discussed sediment. Arupjyoti Saikia's biography of the Brahmaputra River provides extensive discussion of the river's sedimentary regime, and of the role of sediment in complicating navigation, dam building and flood control attempts (Saikia 2019). Debjani Bhattacharyya's history of Calcutta investigates the legal and economic tools devised to appropriate the shifting sedimentary landscapes of the Bengal Delta (Bhattacharyya 2018).

These contributions show significant progress toward the study of the social and historical life of sediment. In none of these works, however, is sediment itself the principal analytical focus. We believe it points to a broader, structural lack of systematic mutual engagement between these disciplines, and especially between political ecology, environmental and water history, and fluvial geomorphology. The lack of systematic engagement with fluvial geomorphology is particularly striking when compared with long-standing engagement of environmental history and political ecology with ecological sciences. This collection of papers helps to move into this new and exciting direction.

\section{The papers of this issue}

The papers in this issue engage in a systematic dialogue between disciplines. The seven papers come from different disciplinary traditions and in many cases include collaboration among historians, archeologists, political ecologists and fluvial geomorphologists. All of them put sediment at the center of the inquiry and engage with the social and historical lives of sediment. In this section, we survey some of the most significant insights that emerge from this novel perspective and interdisciplinary engagement.

One of the central insights of these articles is the existence of long-standing and varied forms of sediment knowledge and management throughout history and across continents. Husain provides a rich example in his study of the strategies enacted by the Ottoman Empire to manage sedimentation processes in the Tigris and Euphrates Rivers (Husain 2020). In the Early Modern period, specific regulations controlled dredging, which the imperial administration outsourced to local communities through corvées. Furthermore, human engineering in this period had a broader geomorphological impact via its interaction with sediment fluxes at the basin scale. Husain suggests indeed that "a canal project that had gone awry," in combination with unusual drought conditions and increased sedimentation, might have caused a major avulsion of the Euphrates in the eighteenth century. In their paper on the Rhône River in France, Guerrin, Comby, and Morera offer rich evidence of Early Modern knowledge and management of sediment (Guerrin et al. 2021). In the Rhône River basin, farmers considered sediments as a blessing for their fertilizing properties, and investors used them to reclaim wetlands in the lower stretches of the river and in its delta. Colten's paper (Colten 2020) provides evidence of purposeful sedimentation from the lower Mississippi River in the early nineteenth century, where deposition was induced as a strategy to reclaim wetlands, and sedimentary landscapes were the objects of contested regulations.

The scaling up of river engineering in the nineteenth and twentieth century had an unprecedented impact on sediment fluxes. States and private companies embanked, diverted, dammed, and mined most rivers of the world, with major consequences on the continuity of sediment fluxes from source to sink. Another central insight of this collection is that the understanding of the implications of these alterations came slowly, 
and the institutional and policy responses came even more slowly. As discussed by Colten (2020), geographer Richard Russell sounded the alarm in 1936 about sediment deprivation linked to the Mississippi river engineering and flood protection works. However, river managers and engineers did not take the issue seriously for most of the twentieth century. Coastal land loss linked to sediment starvation emerged as an issue in the literature only in the 1970s and 1980s, and the role of sediment in coastal restoration became an object of policy debate only the late twentieth century. The Po River and its delta, discussed by Parrinello, Bizzi, and Surian, has a similar trajectory (Parrinello et al. 2021). While river experts understood and measured sediment fluxes from the beginning of the twentieth century, and identified early effects of anthropogenic impact, they did not consider sediment scarcity until the 1970s. Even when scientists started to alert about the issue, policy-makers were slow to respond. While regulations to counter sediment scarcity were passed in 1983, these remained at the local level, and did not tackle scarcity at the basin scale until the turn of the twenty-first century.

A third, central insight of this collection is that sediments have been co-actors of scientific controversies and political conflicts. In their multidisciplinary study of the sedimentary consequences of gold mining in California and Australia, Lawrence and coauthors provide ample evidence of this (Lawrence et al. 2021). In both cases, mining generated massive erosion over a short period of time, which modified the flood regime of rivers downstream. Downstream sedimentation became the subject of conflicts in Australian courts. Moreover, the contamination of sediment with mining byproducts has consequences that reach to the present, making the polluted material and its management controversial and contested among different actors. The controversial nature of sediment is also central to Guerrin, Comby, and Morera's account of the Rhône (Guerrin et al. 2021). In that basin, the contamination of sediment due to past industrial activities has motivated the opposition of farmers and downstream water users to flushing sediments from reservoirs and other projects to restore sediment connectivity. The exploration of sediment's contested social and political lives is also at the center of Swayamprakash's paper on the Detroit River (Swayamprakash 2021). Sedimentary landscapes resulting from dredging "waste" over the twentieth century became coveted natural spaces, generating conservationist expectations and an international controversy between Canada and the United States. Sediment lives are not always peaceful, and their different properties have been historically be mobilized in different, often conflicting ways. The history of sediment lives, in other words, is political.

Finally, the papers gathered in this collection show how thinking historically about sediment can open up broader vistas on human agency, deep time, and the novelty of the Anthropocene epoch. Parrinello, Bizzi, and Surian reflect on the challenges of taking into account the long-term consequences of anthropogenic impact on sediment fluxes in knowledge and management. These challenges point to the broader "limits of environmental policy in regulating large-scale processes that span multiple generations." The articulation between the time scale of policy and engineering and the time scale of sedimentary processes is at the heart of Stahl's paper. Stahl (2021) moves from the example of a dam planned and built in twentieth-century Turkey as a sediment-trapping infrastructure, and provides an original re-reading of geologist Derek Ager's work on stratigraphy (Ager 1973). In what he calls a "stratigraphical model for modern history," Stahl shows how anthropogenic sedimentation demands that we open the writing of history to multiple overlapping temporalities. These discussions show the potential of a historical approach to sediment to contribute to the emerging literature on "geosocialities" (Palsson and Swanson 2006; Yusof 2018) with an increasing sensitivity to 
time, both historical and geological. They also show the potential of a geomorphologically-informed river and water history for contributing to debates on the Anthropocene (Evenden 2018).

\section{The social and historical lives of sediment}

The papers collected in this issue ultimately show the many ways in which it is possible to study historically the social life of sediment, as well as the value of interdisciplinary approaches.

Clearly, there is a lot to gain by adopting such perspectives. First, it leads to a new historical understanding of rivers as consisting of more than just water, thus moving past the water bias that in our opinion characterizes much of the river and water history literature. This, in turn, opens up a space to revisit river development processes that have rarely been studied under this lens, such as dam building or irrigation, and their politics. But it opens also an analytical space to processes rarely studied in history, such as the history of sediment mining for the construction industry, the history of sediment knowledge and monitoring, and the history of sediment regulation. Second, the social life of sediment also has the potential to revise some deeply seated accounts about river and water history, opening up new connections and different explanations for both river processes and human actions and choices. Finally, this can lead to thinking about geomorphological agency in history in new ways and opening up new avenues for interdisciplinary collaborations between historians and geomorphologists, such as those that have shaped this very collection.

There is, as always, much more to do. One of the major challenges of interdisciplinary research on sediment and society will be to expand the time scale of observation and write longer histories of sedimentary changes as social processes. Likewise, we believe more could be done to expand the spatial scale of analysis to focus more systematically on the circulation of sediment at the river basin scale. Finally, huge rewards await studies that will be able to follow the social "transmutation" of sediment along its journey from source to sink: how it is perceived by river basin residents, managers, and scientists (when indeed it is perceived at all), how it is managed, how processes and management actions in one zone of the river basin affect processes elsewhere, and which conflicts emerge out of this. Sediment has mostly been neglected in social discourse and the literature, or has played the role of a supporting actor at best, rather than seen as a leading actor. But there are insights to gain if we take a sediment-centric perspective, as this allows us to see interconnections, relations, and causalities that may not be evident otherwise. We hope this special issue will encourage more to adopt such a perspective.

Acknowledgements This article, and the special issue it introduces, are the result of a collaboration between the two co-authors that started in 2017. We acknowledge gratefully the support of a UC Berkeley Social Science Matrix-Sciences Po collaboration grant, a France Berkeley Fund grant, and an Émergence(s) grant from the City of Paris for the project "Shifting Shores: An Environmental History of Morphological Changes in Mediterranean River Deltas in the Twentieth Century" https://shiftshores.hypotheses.org, of which this is an output. The workshop in Berkeley in 2019 that prepared the ground for this special issue was also generously supported by the Institute of International Studies Interdisciplinary Faculty Seminar Water Management: Past and Future Adaptations, and the Department of Landscape Architecture and Environmental Planning at UC Berkeley. We would like to thank all the participants for their contributions, and one anonymous reviewer and Dr. Santiago Gorostiza for his insightful comments on an earlier version 
of this text. Many thanks also to the editors of Water History Dr. Ellen Arnold and Dr. Maurits Ertsen for accepting to host this special issue and accompanying it to publication.

Open Access This article is licensed under a Creative Commons Attribution 4.0 International License, which permits use, sharing, adaptation, distribution and reproduction in any medium or format, as long as you give appropriate credit to the original author(s) and the source, provide a link to the Creative Commons licence, and indicate if changes were made. The images or other third party material in this article are included in the article's Creative Commons licence, unless indicated otherwise in a credit line to the material. If material is not included in the article's Creative Commons licence and your intended use is not permitted by statutory regulation or exceeds the permitted use, you will need to obtain permission directly from the copyright holder. To view a copy of this licence, visit http://creativecommons.org/licenses/by/4.0/.

\section{References}

Ager DA (1973) The nature of the stratigraphical record. Wiley, New York

Appadurai A (ed) (1986) The Social life of things: commodities in cultural perspective. Cambridge University Press, Cambridge

Ashmore P (2015) Towards a sociogeomorphology of rivers. Geomorphology 251:149-156. https://doi. org/10.1016/j.geomorph.2015.02.020

Ashmore P (2018) Transforming Toronto's rivers: a socio-geomorphic perspective. In: Lave R, Biermann C, Lane S (eds) The Palgrave handbook in critical physical geography. Palgrave Macmillan, Cham, pp 485-511

Ayrault S, Meybeck M, Mouchel J-M et al (2021) Sedimentary archives reveal the concealed history of micropollutant contamination in the Seine River Basin. In: Flipo N, Labadie P, Lestel L (eds) The Seine River Basin. Springer International Publishing, Cham, pp 269-300

Barca S (2010) Enclosing water: nature and political economy in a Mediterranean valley, 1796-1916. White Horse Press, Cambridge

Barra MP (2021) Good sediment: race and restoration in coastal Louisiana. Ann Am Assoc Geogr 111:266-282. https://doi.org/10.1080/24694452.2020.1766411

Benson ES (2020) Random river: Luna Leopold and the promise of chance in fluvial geomorphology. J Hist Geogr 67:14-23. https://doi.org/10.1016/j.jhg.2019.10.007

Bhattacharyya D (2018) Empire and ecology in the Bengal Delta: the making of Calcutta. Cambridge University Press, Cambridge

Bouleau G (2014) The co-production of science and waterscapes: the case of the Seine and the Rhône Rivers, France. Geoforum 57:248-257. https://doi.org/10.1016/j.geoforum.2013.01.009

Bravard J-P (2018a) Crises sédimentaires du globe 1: grand cours d'eau, de l'abondance à la rareté. ISTE Editions, London

Bravard J-P (2018b) Crises sédimentaires du globe 2: deltas, une crise environnementale majeure. ISTE Editions, London

Bremner L (2020a) Sedimentary logics and the Rohingya refugee camps in Bangladesh. Polit Geogr 77:102109. https://doi.org/10.1016/j.polgeo.2019.102109

Bremner L (2020b) Sedimentary ways. GeoHumanities. https://doi.org/10.1080/2373566X.2020.17997 18

Carse A, Lewis JA (2017) Toward a political ecology of infrastructure standards: or, how to think about ships, waterways, sediment, and communities together. Environ Plan A 49:9-28. https://doi.org/10. $1177 / 0308518 X 16663015$

Carse A, Lewis JA (2020) New horizons for dredging research: the ecology and politics of harbor deepening in the southeastern United States. WIREs Water 7:e1485. https://doi.org/10.1002/wat2.1485

Cazzola F (1990) Terra e bonifiche nel delta padano (secoli XV-XVIII). In: Cazzola F, Olivieri A (eds) Uomini, terra e acque: politica e cultura idraulica nel Polesine tra Quattrocento e Seicento : atti del XIV Convegno di studi storici organizzato in collaborazione con l'Accademia dei Concordi, Rovigo, 19-20 novembre 1988. Minelliana, Rovigo, pp 11-24

Cioc M (2002) The Rhine: an eco-biography, 1815-2000. University of Washington Press, Seattle

Colten CE (2020) Redirecting sediment and rearranging social justice. Water Hist. https://doi.org/10.1007/ s12685-020-00255-3

Cortesi L (2018) The muddy semiotics of mud. J Polit Ecol 25:617-637. https://doi.org/10.2458/v25i1. 22945 
Crutzen PJ (2002) Geology of mankind. Nature 415:23-23. https://doi.org/10.1038/415023a

Crutzen PJ, Stoermer EF (2000) The “Anthropocene.” IGBP Newsl 41:17-18

de Freitas JG (2020) Making a case for an environmental history of Dunes. Anthropocenes Hum Inhuman Posthuman 1:5. https://doi.org/10.16997/ahip.4

de Micheaux FL, Mukherjee J, Kull CA (2018) When hydrosociality encounters sediments: transformed lives and livelihoods in the lower basin of the Ganges River. Environ Plan E Nat Space 1:641-663. https://doi.org/10.1177/2514848618813768

Devienne E (2020) La ruée vers le sable : Une histoire environnementale des plages de Los Angeles au $\mathrm{XXe}$ siècle. Editions de la Sorbonne, Paris

Ding X (2020) "The Yellow River Comes from Our Hands": silt, hydroelectricity, and the Sanmenxia Dam, 1929-1973. Environ Hist. https://doi.org/10.3197/096734019X15631846928729

Duperrex M (2019) Voyages en sol incertain: enquete dans les deltas du Rhone et du Mississippi. Wildproject, Paris

Ertsen MW (2016) Improvising planned development on the Gezira Plain, Sudan 1900-1980, 1st ed. 2016. Palgrave Macmillan, Houndsmills, Basingstoke, Hampshire, New York

Evenden MD (2004) Fish versus power: an environmental history of the Fraser River. Cambridge University Press, Cambridge, New York

Evenden M (2018) Beyond the organic machine? New approaches in river historiography. Environ Hist 23:698-720. https://doi.org/10.1093/envhis/emy054

Gilbert GK (1917) Hydraulic-mining débris in the Sierra Nevada. Department of the Interior, United States Geological Survey, Washington

Guerrin J, Comby E, Morera R (2021) From asset to threat: trajectory of sediment on the Rhône River. Water Hist. https://doi.org/10.1007/s12685-021-00276-6

Hohensinner S, Sonnlechner C, Schmid M, Winiwarter V (2013) Two steps back, one step forward: reconstructing the dynamic Danube riverscape under human influence in Vienna. Water Hist 5:121-143. https://doi.org/10.1007/s12685-013-0076-0

Hooke RL (2000) On the history of humans as geomorphic agents. Geology 28:843-846. https://doi.org/ 10.1130/0091-7613(2000)28\%3c843:OTHOHA\%3e2.0.CO;2

Husain, F (2020) Sediment of the Tigris and Euphrates rivers: an early modern perspective. Water Hist. https://doi.org/10.1007/s12685-020-00256-2

Kelley RL (1959) Gold Vs. grain, the hydraulic mining controversy in California's Sacramento Valley: a chapter in the decline of the concept of Laissez Faire. A.H. Clark Company, Glendale

Kondolf GM (1994) Geomorphic and environmental effects of instream gravel mining. Landsc Urban Plan 28:225-243. https://doi.org/10.1016/0169-2046(94)90010-8

Kondolf GM, Piégay H (2011) Geomorphology and society. In: Gregory K, Goudie A (eds) The SAGE handbook of geomorphology. SAGE Publications Ltd, London, pp 105-118

Kondolf GM, Gao Y, Annandale GW et al (2014) Sustainable sediment management in reservoirs and regulated rivers: expesriences from five continents. Earth's Future 2:256-280. https://doi.org/10. 1002/2013EF000184

Latour B (2007) Reassembling the social: an introduction to actor-network-theory. Oxford University Press, Oxford, New York

Lave R, Biermann C, Lane S (eds) (2018) The Palgrave handbook of critical physical geography. Palgrave Macmillan, London

Lawrence S, James A, Grove J et al. (2021) Society and sediment in the Mining Rivers of California and Australia. Water Hist. https://doi.org/10.1007/s12685-020-00273-1

MacFarlane D (2014) Negotiating a river: Canada, the US, and the creation of the St. Lawrence Seaway. University of British Colombia Press, Vancouver

McNamara DE, Werner BT (2008) Coupled barrier island-resort model: 1. Emergent instabilities induced by strong human-landscape interactions. J Geophys Res Earth Surf 113:1-10. https://doi. org/10.1029/2007JF000840

McNeill J (1992) The mountains of the Mediterranean world: an environmental history. Cambridge University Press, Cambridge, New York

McNeill J, Winiwarter V (eds) (2010) Soils and societies: perspectives from environmental history. White Horse Press, Cambridge

Meade RH (1982) Sources, sinks, and storage of river sediment in the Atlantic drainage of the United States. J Geol 90:235-252.https://doi.org/10.1086/628677

Molle F (2009) River-basin planning and management: the social life of a concept. Geoforum 40:484494. https://doi.org/10.1016/j.geoforum.2009.03.004

Muscolino MS (2020) The contradictions of conservation: fighting erosion in Mao-Era China, 1953-66. Environ Hist Durh N C 25:237-262. https://doi.org/10.1093/envhis/emz116 
Palsson G, Swanson HA (2016) Down to earth: geosocialities and geopolitics. Environ Humanit 8:149-171. https://doi.org/10.1215/22011919-3664202

Parrinello G, Bécot R, Caligari M, Yrigoy I (2019) Shifting Shores of the Anthropocene: the settlement and (unstable) stabilisation of the North-Western Mediterranean Littoral over the nineteenth and twentieth centuries. Environ Hist. https://doi.org/10.3197/096734019X15740974883816

Parrinello G, Bizzi S, Surian N (2021) The retreat of the delta: a geomorphological history of the Po river basin during the twentieth century. Water Hist. https://doi.org/10.1007/s12685-021-00279-3

Pietz DA (2015) The Yellow River the problem of water in modern China. Harvard University Press, Cambridge

Pritchard SB (2011) Confluence. Harvard University Press, Cambridge

Saikia A (2019) The unquiet river: a biography of the Brahmaputra. Oxford University Press, New Delhi

Stahl D (2021) The dam as catastrophe: connecting geological models to modern history. Water Hist. https:// doi.org/10.1007/s12685-021-00278-4

Steffen W, Grinevald J, Crutzen P, McNeill J (2011) The Anthropocene: conceptual and historical perspectives. Philos Trans R Soc Lond A Math Phys Eng Sci 369:842-867. https://doi.org/10.1098/ rsta.2010.0327

Steinberg T (1991) Nature incorporated: industrialization and the waters of New England. Cambridge University Press, Cambridge, New York

Swayamprakash R (2021) Sedimentality: sediment landscapes, socio-politics, and the environment in the Lower Detroit River. Water Hist. https://doi.org/10.1007/s12685-021-00277-5

Swyngedouw E (2015) Liquid power. Contested hydro-modernities in twentieth-century Spain. The MIT Press, Cambridge, London

Syvitski JPM, Kettner A (2011) Sediment flux and the Anthropocene. Philos Trans R Soc Lond A Math Phys Eng Sci 369:957-975. https://doi.org/10.1098/rsta.2010.0329

White R (1995) The organic machine: the remaking of the Columbia River. Hill and Wang, New York

Williams GP, Wolman MG (1984) Downstream effects of dams on Alluvial Rivers. United States Government Printing Office, Washington, D.C

Winiwarter V, Schmid M, Dressel G (2013) Looking at half a millennium of co-existence: the Danube in Vienna as a socio-natural site. Water Hist 5:101-119. https://doi.org/10.1007/s12685-013-0079-x

Worster D (1985) Rivers of empire: water, aridity, and the growth of the American West/Donald Worster. Pantheon Books, New York, p 1985

Yusoff K (2018) A billion black Anthropocenes or none. University of Minnesota Press, Minneapolis

Zhang L (2016) The river, the plain and the state: an environmental drama in Northern Song China, 1048-1128. Cambridge University Press, Cambridge

Zografos C (2017) Flows of sediment, flows of insecurity: climate change adaptation and the social contract in the Ebro Delta, Catalonia. Geoforum 80:49-60. https://doi.org/10.1016/j.geoforum.2017.01.004

Publisher's Note Springer Nature remains neutral with regard to jurisdictional claims in published maps and institutional affiliations. 